\title{
Zoological taxonomy at 250: showcasing species descriptions in the cyber era
}

\author{
ZHI-QIANG ZHANG \\ Landcare Research, Private Bag 92-170, Auckland, New Zealand \\ E-mail:ZhangZ@landcareresearch.co.nz
}

January 1, 2008 marks the 250th anniversary of the official publication date of Systema Naturae (Linnaeus 1758) recognized by ICZN (1999). During the last two and a half centuries, Linnaeus (1758)' system for naming, ranking and classifying organisms has allowed us to document the pattern of life on Earth, Darwin (1850)'s theory of evolution has helped us to understand the process how this diversity of life came about, and Hennig (1966)'s phylogenetic methodology has enabled us reconstruct the tree of life. During the last two decades or so, the internet has dramatically changed the way we live and work. The rapid advances in bioinformatics have provided taxonomists unprecedented opportunities to do their research more efficiently and make their findings more accessible. Cybertaxonomy is emerging as an exciting new branch of taxonomy (Wheeler 2007).

Showcased here is an exemplar paper by Pyle et al. (2008: 3-31) who described five new species of damselfish (Chromis) from deep coral reefs in the tropical western Pacific. This is the first taxonomic paper integrating many of the most recent cybertaxonomic tools with species descriptions and demonstrating the utility of international standards for biodiversity informatics. The online edition of this paper has been specially formatted with many embedded links to many resources available online via the internet to enhance access to taxonomically-relevant information:

- $\quad$ The new species represent the first five scientific names prospectively registered in the official ZooBank registry developed by the International Commission on Zoological Nomenclature (http://www.iczn.org/)

- The descriptive data related to all specimens of the new species, as well as comparative data for other species, have been marked up with SDD (TDWG standard for descriptive data such as characters, etc. http://www.tdwg.org/activities/sdd/), so that the raw data can be downloaded directly as XML and/or other formats

- The species descriptions themselves have been marked up with XML tags using standards in TaxonX (http:// research.amnh.org/informatics/taxlit/schemas) and taXMLit11 (http://www.sil.si.edu/digitalcollections/bca/documentation/taXMLitv1-3Intro.pdf)

- The images (both published in the article itself, and others not included in the article) have been deposited in the MorphBank (http://www.morphbank.net/), with embedded links in the PDF file itself to the MorphBank images or image collections

- The cited specimens have embedded links to their respective Museum online databases (when available) and/or via the GBIF portal (http://data.gbif.org/welcome.htm)

- DNA Barcodes have been deposited in GenBank (http://www.ncbi.nlm.nih.gov/Genbank/), in compliance with the Barcode of Life Data Systems (BOLD, http://www.barcodinglife.org) and associated Fish Barcode of Life Initiative (http://www.fishbol.org)

- $\quad$ References cited have been registered with ZooBank, and some are available as full-page images through the Biodiversity Heritage Library (BHL, http://www.biodiversitylibrary.org/).

The making of this paper (Pyle et al. 2008) has been a truly international collaboration between the authors and bioinformatics workers. Published symbolically on the 250th anniversary of the publication of Systema Naturae (Linnaeus 1758) and the official launch of the ZooBank registry, it is hoped that this exemplar paper will help demonstrate the value of bioinformatics standards in enhancing the work of all taxonomists throughout the next quartermillennium and beyond.

Acknowledgements. I thank Richard Pyle for taking the initiative in preparing his exemplar paper and for commenting on the draft of this editorial. 


\section{References}

Darwin, C.R. (1859) On the Origin of Species by Means of Natural Selection, or the Preservation of Favoured Races in the Struggle for Life. John Murray, London.

Hennig, W. (1966) Phylogenetic Systematics. University of Illinois Press, Urbana.

ICZN [International Commission on Zoological Nomenclature] (1999) International code of zoological nomenclature. Fourth edition. International Trust for zoological Nomenclature, London, $335 \mathrm{pp}$.

Linnaeus, C. (1758) Systema Naturae per regna tria naturae, secundum classes, ordines, genera, species, cum characteribus, differentiis, synonymis, locis. Editio decima, reformata. Tomus I. Laurentii Salvii, Holmiae, 828 pp.

Pyle, R.L., Earle, J.L. \& Greene, B.D. (2008) Five new species of the damselfish genus Chromis (Perciformes: Labroidei: Pomacentridae) from deep coral reefs in the tropical western Pacific. Zootaxa, 1671, 3-31.

Wheeler, Q.D. (2007) Invertebrate systematics or spineless taxonomy? Zootaxa, 1668, 11-18. 